\title{
IMPACT OF TOURISM ON ROUNDABOUT OF ECONOMIC PROCESS
}

\author{
Slavoljub Vujović1, Nikola Ćurčićc ${ }^{2}$ Vuk Miletic ${ }^{3}$
}

\section{Summary}

The relation between of production and consumption units, market mechanisms, and the behaviour of economic subjects in the market are aspects that enable an understanding of tourism in the economic process.

Two basic factors of tourism "free time and free money" as the goal of creation of each individual, striving to meet the needs for luxury, rest, rehabilitation and recreation, are directly linked to the basic economic relationship, the relationship between limited resources and unlimited needs. Not respecting the principles and rules of the socio-economic sphere, by the dynamics of the development of techno-economic sphere, the increasing difference between the poor majority and rich minority in the world, causing many economic and social problems. Given the economic problems on a global level, further directions of development of tourism should be sought through the analysis of the relationship, or better to say, interdependence of development of techno-economic and socio-economic spheres. This paper seeks to determine and clarify the importance of tourism as a factor stimulating circular flow of economic processes.

Key words: tourism, economics, development, economy.

JEL: $Q 11, Q 17, Z 32$.

1 Slavoljub Vujović, Ph.D., Senior research fellow and Professor of professional studies, Belgrade Business School, Higher education institution for applied studies, Kraljice Marije street no. 73, 11000 Belgrade, Republic of Serbia, Phone: +381 113042 328, E-mail: kelovic1967@yahoo.com

2 Nikola V. Ćurčić, Ph.D. student, University Union Nikola Tesla, Faculty of Management, Sremski Karlovci, Serbia,Phone: +381 64277 7771, E-mail: nikolavcurcic@yahoo.com

3 Vuk Miletić, M.Sc., Ph.D. student, University Business Academy, Faculty of Applied Management, Economics and Finance, Nemanjina Street no. 4, 11000 Belgrade, Serbia; +381 112643 390, E-mail: vukmiletic@gmail.com 


\section{Introduction}

The expansion of economic and a number of other related problems, reflected through the prism of finances in developed economies, is becoming wider and wider, flooding other less developed economies with the same problems, thus creating all the bigger gap between the rich and the poor. A specific role of tourism in the context of an economic process is to absorb, alleviate and solve in a specific manner a number of economic problems with its influences in an economic process and constant incentives to production and consumption units.

These problems are connected with a demographic factor (the number of inhabitants, an uneven population, birth rates, etc.), natural resources (the amount, the relation of man towards resources and exploitation), energy and food, the control and distribution of national income, and up to the fundamental flows of an economic process.

The influence of tourism (foreign) on the balance of payments and GDP (gross domestic product) overflow between certain economies of the world is especially significant. One of particularities of tourism is that the functioning of tourist supply and demand leads to the overflow of personal incomes from one country into the other, without any agreements between governments, without international conventions, declarations and etc.

So, the mechanisms of tourist supply and demand enable the export of material and immaterial values at home, without formal procedures of packing, customs procedures, shipping, and other foreign trade procedures. It is especially interesting to mention the export of immaterial values at home, those which cannot be packed (adventures, spiritual and emotional feelings, and all those values which make the timeless heritage of oral tradition of a people), standardized and sold like other products and services (Guzina, 2009).

However, if all financial power centers, financial institutions and the latest technologies are in the developed economies of the world, this raises the question of the causes of economic crises and why financial problems occur in these economies. Is the concept of neoliberal capitalism the leading problem and how does it affect global tourist flows?

All powerful alliances and world bloc divisions (it refers primarily to the NATO and EU) on a planetary level seek a solution for economic problems, in the sense of creating new markets. They strive to solve the sales problem, as one of the central problems of developed countries. It is not a problem for developed economies to produce anything, the problem is where and how to sell it.

Large corporations have imposed a completely new concept of the regulation of socioeconomic relations, the so called "corporatocracy".

The essence of "corporatocracy" is that large corporations - their leaders - or rather financial politicians, dictate tasks to politicians in government structures, how to project legislative and legal framework, what policies to lead, where to initiate wars etc., and all with the aim of enormously increasing their own financial capital. 
However, even the corporatocracy has problems, because being the engine of neoliberal capitalism it leads to the collapse of basic economic postulates, to the creation of a bigger and bigger gap between a techno-economic and socio-economic sphere, and to a bigger and bigger gap between the poor and the rich, to the collapse of the functioning of labour market mechanisms and goods and services market mechanisms, to the disrespect of basic human rights etc. It leads to the collapse of the constitutional and legal order, and in this way to the malfunctioning of the systems for the control of creation and distribution of newly created values. The inadequate system of primary and secondary distribution represents a special problem.

In addition to his claim, which he expressed on the summit in Lindau, that the accelerated increase of the gap between the rich and the poor, which was in those days turning into a burning issue, would have enormous economic consequences, the famous Nobel prize winner Joseph Stiglitz (the chief economist of the World bank from 1997 to 2000) cited the data that $95 \%$ of the USA national income went into the pocket of only one per cent of people, that average salaries were lower than a quarter-century before, that the rich were becoming richer, and the poor were becoming poorer, and the same situation was in many other countries.

The key factor lay, as Stiglitz cited, in the fact that it had not been invested enough in the informing of the widest population, who still believed in fallacies such as the American dream about a man who started his career as a dish washer and then the arduous work led him to the status of a millionaire. When it comes to the economy of the European continent, Stiglitz cited that wealth divisions on the old continent were less uneven than in the USA, thanks to the strong middle class in Germany and Scandinavia. In the other part of Europe the disproportion was much bigger. It was also interesting that the American trend of development disproportion and wealth distribution was closely followed by China. "In its economy, which is in vertiginous ascent, $95 \%$ of its wealth is concentrated in the hands of barely 5\% of people" (Stiglitz, 2014).

With no intention to disprove the attitude of Stiglitz, we believe that economic poverty is a bigger problem than the problem of informing the widest population who, as he cited "still believes in fallacies, such as the American dream about a man who starts his career as a dish washer, and then the arduous work leads him to the status of a millionaire".

However, apart from all above mentioned problems, tourism, globally observed, has a positive growth rate. As well as other sectors on a global level, tourism has also felt the pressure of the global economic crisis. The world economic situation after 2007/2008 has put additional pressure on the psychophysical state of people and their health. People more often seek new ways of having a holiday and relaxation. Due to the economic crisis some forms of tourism, on a global level, are slowed down, however, the tourist sector on the whole has been in an extremely good position over the last two or three years offering new models of tourism, such as Wellness tourism (Koncul, 2012). If a certain destination, zone or region possesses quality inorganic, organic and anthropogenic elements, tourism is certainly an activity which enables 
its economic development and more efficient inclusion in the international division of labour (Vujović, 2011).

Tourism is directly incorporated in three out of four (extractive industry, agriculture, processing industry and traffic) basic areas of material production - traffic, processing industry and agriculture.

"Apart from extractive industry, agriculture and processing industry, there is also the fourth area of material production, which also goes through diverse stages of craft, manufacturing and mechanical work - it is transport industry (Locomotion industry) whether it transports people or goods" (Marx, 1978).

According to above mentioned attitudes, it can be said for tourism that it is the first (or one) out of five basic areas of material production. Given the fact that there is a multiple direct connection between tourism and traffic, between agriculture and processing industry, and if we exclude extractive industry, tourism is then one of the four basic areas of material production.

Countries with developed tourism can, thanks to incomes from tourism, compensate for necessary goods of extractive industry, and so tourism can be treated as the first out of four basic areas of material production (tourism, agriculture, traffic and processing industry).

\section{Methodology}

On the basis of research literature and analysis of the results, the authors sought to examine the initial research hypotheses that tourism directly stimulates the economic development in many ways, especially clarifying the impact of tourism on GDP (gross domestic product), $\mathrm{NI}$ (national income) and the multiplier effect of tourism on the economy.

Famous theorist development aspects of tourism Dulčić (2001), other than specified performance, highlights and other (employment, the development of underdeveloped areas, etc.) the positive effects of tourism on the economy.

The world famous founders of theoretical knowledge and learning on tourism, Krapf and Hunziker (1942), analyze developmental aspects of tourism in the wider context, giving special importance to the economy of tourism. Interestingly, the world-renowned theorist tourism Krippendorf (1986), through the analysis of the negative impacts of tourism on the natural and the life environment, indirectly associated developmental aspects of tourism to economic development.

According to the defined purpose of the research has dominated economic analysis of the economic effects of tourism and developing a theory of the research results.

In order to respect the principle of contradiction and the principle of sufficient reason used the knowledge and skills of ontology. Also, there were used: the method of correlation, historical and comparison method. 


\section{Tourism in the light of inconsistency between techno-economic and socio- economic sphere development}

Given the financial breakdowns and economic problems on a global level, the development of tourism as an economic activity in the future, should be sought through the analysis of relations, or rather interdependence of a techno-economic and socio-economic sphere in the context of total economics (Frolov, 2011).

The techno-economic and socio-economic sphere are interconnected according to a cause and effect model. Many economic phenomena, although seemingly unrelated, affect each other to a great extent.

"However, the fact that something is connected does not mean that one conditions another. The connectedness simply proves that there is a certain relation between two factors let's call them factors $\mathrm{X}$ and $\mathrm{Y}$ - but it tells us nothing about the type of that relation. It is possible that $\mathrm{X}$ causes $\mathrm{Y}$; it is also possible that $\mathrm{Y}$ causes $\mathrm{X}$; and it is possible that $\mathrm{X}$ and $\mathrm{Y}$ are only the consequences of some third factor Z" (Steven, Stephen, 2006).

While analyzing the problems of the global "financial" crisis, Frolov (Frolov, 2011) rejects attitudes and opinions of numerous world theoreticians, thus indicating that solutions should be sought in the field of a techno-economic and socio-economic sphere by analyzing economic movements in a shorter and longer period, so called long and short waves. Although authors completely accept the attitudes of Frolov, it should be emphasized that all movements in both cited spheres are conditioned with institutional and evolutional economics, institutions and system institutes. One of the key problems lies in technology control, newly created values of these technologies and their redistribution, where benefits of a techno-economic sphere and newly created wealth do not reach, to a necessary extent, wider, middle and lower classes of a society.

"Economics is primarily the science of measurement. It has an extremely powerful and flexible group of resources with which a mass of data can be precisely processed according to which the influence of any individual factor, or even a joint action of all factors could be estimated" (Steven, Stephen, 2006).

Tourism cannot exist without transformational and transaction technologies, to whose significance in economic movements and economic development Frolov indicates in the context of technological determinism. As Frolov asserts "generally speaking, technologies are a way of using interrelated methods and instruments for the increase of certain activity efficacy according to whose character their classification is made. That is the reason why the delineation between transformational and transaction technologies is methodologically correct" (Frolov, 2011).

It is a fact that new technologies stimulate development, they stimulate the creation of not only a new product, but also new (it refers to expertise, training, and behavior) labour force, a new consumer society, new social norms and standards. "The change of technological orders requires, according to the rule, certain changes in a social and institutional system, which not only eradicate social tension, but also help the mass introduction of technology 
of a new technological order (regime) according to needs and a way of life" (Frolov, 2011). Namely, man is in the centre and he supports innovations, the creation of something new, but he also supports social norms. The success of new technologies (primarily the profit they will bring) depends on how wide they have "thrived" in a society or on the market. For example, it should be mentioned the inventions and discoveries of Nikola Tesla. New technology created by Nikola Tesla has existed for centuries. His contribution on a planetary level is immeasurable. More or less, it is present in all nations and in all spheres of life, while a number of other technologies (e.g. a pager, certain types of mobile phones, etc.) had a short lifetime.

It is true that the techno-sphere requires new changeable capital necessary in technological processes - in production, but it also requires much fictitious capital (embodied) in the very equipment - machines necessary in the production phase. As Daković (1992) claims, technology - machines swallow a lot of live work (so called embodied labour) in the process of creation, while later on in their functioning they require less live but more professional and expensive work. Without respecting the principles and interests of a socio-economic sphere, and in the absence of system institutions the techno-economic sphere will go to uncertainty (Galbraith, 1987).

However, apart from all economic problems and disruptions, also confirmed by empirical research, the only economic activity (or the model of economic development), which, regardless of all disruptions in economy, records further growth, is tourism.

The above mentioned arguments and facts confirm the fact that tourism is an economic activity which in a specific way stimulates growth, uses benefits and connects one and the other sphere. The growth and development of tourism on a planetary level is, on the one hand, inconceivable without new technologies, while on the other, the consumer (or economic) component of tourism stimulates economic growth (the development of economic processes).

\section{Tourism development performances on a global level}

World tourism makes $10 \%$ of the world's total gross domestic product and it generates annual income of more than 1000 billion USD and employs 200 million people (UNWTO, 1998). 
Chart 1. The number of total international tourist arrivals, in billion USD

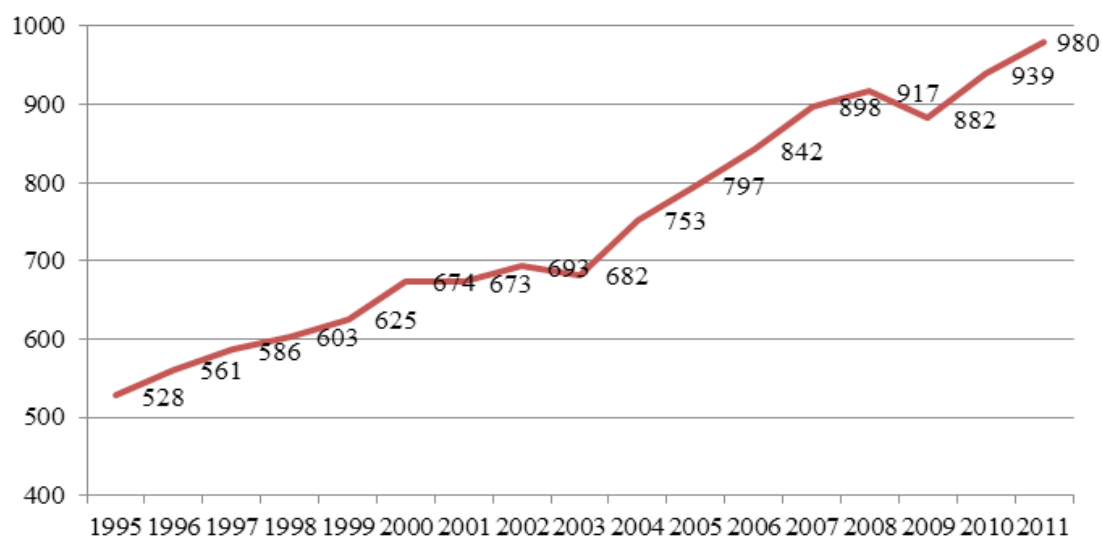

Source: Vujovic, Filipović, Marković, 2012.

Over the last six decades tourism has experienced expansion and diversification, thus becoming one of the biggest and fastest growing sectors of an economy.

Even the data of the World Tourism Organization and the International Monetary Fund (UNWTO, 1998) speak in favour of that and they show that tourism is one of the five leading export activities in $83 \%$ of world countries and the main source of foreign income for at least $38 \%$ of countries.

Despite negative economic movements and political turbulence, the number of international tourist arrivals is on the constant increase (Chart 1).

The global economic crisis had an impact on tourism, but the world tourist industry recovered as soon as 2010 . So, in 2010 a $7 \%$ increase of foreign tourist arrivals was recorded, while in 2011 the number of international tourist arrivals had an increase of $4.6 \%$.

According to the data of the World Tourism Organization, in the first quarter of 2012 the number of total international arrivals was 5\% bigger compared to the same quarter of the previous year. With existing annual growth rates of international tourist arrivals (the average annual growth rate has been $4.4 \%$ since 1990), it is expected that by 2020 there will be about 1.6 billion foreign tourists worldwide (Premović et al., 2012).

Europe is still the leading tourist destination which accounts for more than a half of total tourist visits. During 2011, 504 million tourist arrivals were recorded in Europe. A $6 \%$ increase of visits compared to 2010 secured Europe's position of the leading tourist destination. The increase of international tourist arrivals is especially noticeable in the Mediterranean part of Europe which otherwise accounts for $19 \%$ of world tourism. During 2011 the increase was achieved by Greece $(10 \%)$, Turkey $(+9 \%)$, Portugal $(+9 \%)$, Croatia $(+9 \%)$, Spain $(+8 \%)$ and Italy $(+6 \%)$. It is interesting that other less touristically developed destinations achieved even a double-digit increase: San Marino $(+30 \%)$, Macedonia $(+25 \%)$, Serbia $(+12 \%)$, Montenegro and Cyprus $(+10 \%)$. The increase of tourist visits 
in the Mediterranean part of Europe is the consequence of riots in North Africa and the Middle East, but it is also the consequence of aroused interest of tourists from Scandinavian countries, Russia and Germany.

\section{The influence of tourism on the balance of payments, GDP and NI}

It is common knowledge that tourism as an economic activity, through numerous functions, has an extremely wide and heterogeneous impact on the economy and society. Some theoreticians cite as basic functions: health, technical, cultural-social, economic and political functions. Certain theoreticians cite as basic functions: economic, health, culturaleducational and political functions while others speak about groups of functions - a group of economic functions, as a dominant one, adding to it: health, social, political, educationalcultural functions and a recreational-entertaining function.

In literature on basic questions about tourism, the division to primary and consequential functions is interesting, where under primary functions a group of economic functions is emphasized, and under consequential all other non-economic functions (Bakić, et al., 1999).

According to theoretical researches, realized through literature, as the main division of all functions of tourism, authors of the work cite the division into: economic and noneconomic functions.

As a part of economic functions there stand out functions of direct (influences on the balance of payment, national income, on employment and etc.) and functions of indirect influences (influences on other economic activities), however, one should not forget multiplicative effects and so called other functions of tourism, especially the foreign one. Regardless of all values and knowledge of statistics, hospitality and tourism records and analyses, it is impossible to perform a hundred percent tracking of tourism effects.

With direct influences or effects of tourism on the balance of payments, GDP and NI, incomes obtained from foreign tourists' spending, so called invisible export has special significance. The invisible export gives tourism a special advantage in relation to all other economic activities and sectors. The invisible export and invisible import directly influence the balance of payments of a country, except that the invisible export has a positive impact and the invisible import has a negative one. A positive difference, i.e. bigger invisible export than invisible import, increases the balance of payments, while the opposite situation decreases the balance of payments. Foreign tourists' spending has a direct impact on the overflow of national income between economies, from the countries from which tourists come, a part of national income overflows into the countries in which tourists come and spend.

In the Table 1., there are data of tourism participation in GDP in the world, the EU and individual countries, in the period from 2007 until 2014 and the projection for 2015. According to the data of World Travel \& Tourism Council (WTTC), the total contribution of tourism to GDP in the world in the period from 2007 until 2015 will, on average, amount to $9.25 \%$. 
Table 1. Participation of tourism in GDP, in \%

\begin{tabular}{|l|c|c|c|c|c|c|c|c|c|}
\hline \multirow{2}{*}{$\begin{array}{l}\text { World, region } \\
\text { and country }\end{array}$} & \multicolumn{9}{|c|}{ Year } \\
\cline { 2 - 10 } & $\mathbf{2 0 0 7}$ & $\mathbf{2 0 0 8}$ & $\mathbf{2 0 0 9}$ & $\mathbf{2 0 1 0}$ & $\mathbf{2 0 1 1}$ & $\mathbf{2 0 1 2}$ & $\mathbf{2 0 1 3}$ & $\mathbf{2 0 1 4}$ & $\mathbf{2 0 1 5}$ \\
\hline WORLD & 9.6 & 9.4 & 9.3 & 9.0 & 9.1 & 9.1 & 9.2 & 9.3 & 9.3 \\
\hline Europe & 8.1 & 8.0 & 8.0 & 7.7 & 7.6 & 7.7 & 7.6 & 7.6 & 7.7 \\
\hline EU 27 & 8.3 & 8.1 & 8.1 & 7.8 & 7.8 & 7.8 & 7.8 & 7.8 & 7.9 \\
\hline Croatia & 27.6 & 28.5 & 25 & 26.3 & 27.5 & 29 & 29.7 & 30.1 & 30.5 \\
\hline Macedonia & 5.1 & 5.2 & 5.2 & 5.1 & 5.2 & 5.5 & 5.6 & 5.7 & 5.7 \\
\hline Montenegro & 21.6 & 24 & 16 & 15.7 & 17.1 & 19.7 & 22.9 & 25.5 & 27.4 \\
\hline Serbia & 6,1 & 5.9 & 7.5 & 7.8 & 8.0 & 8.0 & 8.0 & 8.0 & 7.9 \\
\hline Austria & 12.1 & 12 & 12.3 & 11.7 & 11.8 & 12.2 & 12.5 & 12.6 & 12.8 \\
\hline Greece & 17.3 & 16.5 & 15.2 & 15.3 & 15.7 & 16.3 & 16.7 & 16.9 & 17.1 \\
\hline Italy & 9.3 & 8.7 & 8.4 & 8.4 & 8.5 & 8.7 & 8.8 & 8.9 & 9.0 \\
\hline Portugal & 13.6 & 14.2 & 13.3 & 13.8 & 14.7 & 15.1 & 15.4 & 15.6 & 15.7 \\
\hline Spain & 14.9 & 14.9 & 14.7 & 14.3 & 14.3 & 14.4 & 14.4 & 14.3 & 14.3 \\
\hline
\end{tabular}

Source: Đuranović, Radunović, 2011.

Incomes from foreign tourism directly represent a causal correlation between tourism and real economic growth, indicating both at the short-term and long-term connection between them (Norsiah, Karim, 2012).

More concrete tracking of tourism effects on the balance of payments, GDP and NI can be analyzed through GVA (gross value added) where the contributions of individual sectors within tourism (hotel industry, gastronomy, private accommodation, transportation) are concretely followed.

Tourist balance as a part of the total balance of payments, gives a detailed review of all incomes and expenses from tourism. In a broader sense it includes all incomes from the sale of goods and services to foreign tourists, incomes from investments in foreign tourist economies, incomes generated through the export of goods and services for the purposes of foreign economies tourism, then incomes from various taxes paid by foreign tourists, while in the narrow sense it includes only incomes from the "invisible" export (incomes obtained from foreign tourists' spending) and the "invisible" import (all travel expenses of local citizens abroad).

The balance of payments, as above mentioned, is influenced by tourism primarily with incomes from foreign tourists' spending. If a country $\mathrm{X}$, for example, has a deficit in the balance of payments of 10 million dollars (it means that it imports more goods and services than it exports whose value is more than 10 million dollars, in a certain period - most often a year), it can solve its problem if it generates surplus in the tourist balance with that or even bigger amount than 10 million dollars, thus covering the existing deficit of the balance of payments with surplus in the tourist balance.

There are, of course, other situations in practice where, e.g. surplus in the balance of payments in the amount of 18 million dollars, a certain economy increases, if it has also generated surplus in the tourist economy of 8 million dollars, recording total surplus of 26 
million dollars, or e.g. a situation where the generated deficit of 80 million dollars, a certain economy can aggravate if it generates a deficit from tourism incomes in the amount of 4 million dollars, recording the total deficit of 84 million dollars, or a situation when a certain economy covers the generated deficit of 5 million dollars in the tourist balance with surplus of 120 million dollars generated in the balance of payments.

How and how much NP (national product) overflows from specific economies into other economies can be seen through the tourist balance of those economies. Emitting countries are considered to be those countries which overflow part of their NP into other countries on the basis of tourists' spending, thus generating a negative balance in the tourist balance, while countries which generate a positive balance in the tourist balance are considered receptive countries.

\section{Tourism in the function of a stimulating factor of an economic process}

The relation between production and consumption units, market mechanisms (functioning of the market) and the behavior of economic subjects on the market are aspects which enable the understanding of tourism in an economic process.

Two basic factors of tourism "free time and free money" which are on the one hand the aim of human creation and aimed at meeting the needs for luxury, holiday, recuperation and recreation, are in a direct connection with the basic human relation, the relation between limited goods and unlimited needs.

This relation, in turn, leads to the basic relation or condition for man's survival, and that is the relation between man and nature.

"First of all man has to work, i.e. produce diverse goods, so that he could, by using those goods, meet different needs. Nevertheless, his capabilities for goods production are limited because resources are limited, unlike needs which are, as a rule, above production capabilities" (Dulčić, 2001). All goods which man creates (they are not an aim unto themselves, but money and other goods which the same producer buys on the market for money so that he could meet certain needs) are produced in production units (most often in some enterprises), and they are spent by consumers, or man as a consumption unit with the aim of meeting his needs.

As Milanović (Milanović, 2007) cites in Microeconomics, as a branch of economics, the analyses of the behavior of individual economic units, household consumers and producers/ enterprises dominate.

By travelling and spending his earned money and free time with the aim of meeting his needs, man, in the role of a tourist, again sets in motion a number of production units (hoteliers, caterers, food producers, traffic, a construction sector, numerous agents on the tourist market, etc.). 
Chart 2. Production and consumption units in an economic process

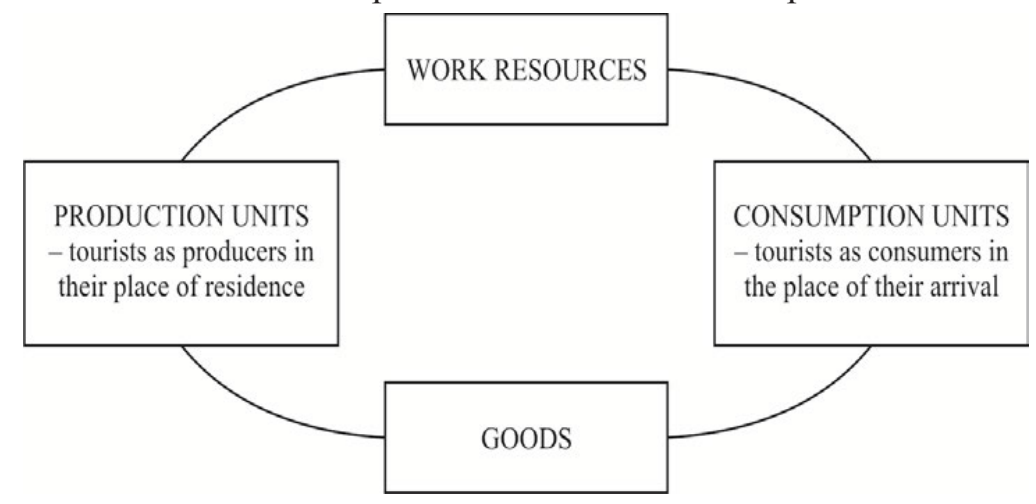

Source: Dulčić, 2001.

Namely, money earned in production units a tourist spends without excluding it from an economic process, but striving to meet his own tourist needs with the money, he sets in motion a number of other production units where the production and consumption process continues (Chart 2).

As Dulčić cites "Production is not an aim unto itself, but man works so that he could survive and perform other numerous activities. Keyns (John Maynard Keyns) will say: consumption is the only aim and the sole purpose of the entire economic activity" (Dulčić, 2001).

According to conventional definitions and acceptance of terms "a tourist and tourism" Keyns's thesis implies the essence of tourism.

A constant desire for change, understanding of new things or emphasizing "bad adaptation" with all levels of a social community, generates consumption, which in the context of economic processes - economic development gives tourism an advantage in relation to other economic activities. If a consumer has limited free time and free money, as a consequence there will be reduction in consumer goods and services production and consumption.

The relation between resources and needs indicates that all man's efforts are directed towards harmonizing needs and capabilities. Tourists' needs are manifested through the tourist's spending, and they are quantified with the amount of spent-bought.

Dominance of commercial motives on the supply side gives an advantage to an economic approach and economic interests, while, a spatial approach implies, as a benchmark or basis always a certain destination or a tourist spot (Vujović et al., 2011).

According to above mentioned attitudes connected with the defining of tourism in an economic process, through relations between production and consumption units, it is necessary to underline that the market mechanism is unavoidable.

A systematic approach to the market, in the context of the above emphasized economic process, implies functioning of the goods-services market and factors market, as subsystems 
or partial markets. Participants in an economic process on these partial markets establish mutual relations in which prices and amounts of required goods and services are determined.

\section{Conclusion}

Factors "free time and free money" as a prerequisite for tourism development, are conditioned with a basic economic problem "a gap between unlimited needs and limited capabilities". Here the question arises as to what "free money" is, or, after meeting which needs the rest of the money can be considered free money. However, it can be assumed that anyone who appears in the role of a tourist has previously met certain levels or groups of needs - existential, safety, etc.

Basic factors of economics: work, land and capital, with later added also as basic: information, time and space, tourism implies as basic factors of tourism development, except that in the foreground of previous six factors tourism sets man, as the holder of free time and free financial means and the holder of development.

Fundamental questions of economics: what should be produced, how and for whom, have the same significance and role even in tourism - which tourism goods and services should be produced, with which technologies and for whom (which markets) should they be produced.

Factors which influence the behavior of consumers in tourism as subjects of consumption: tourists' needs, income and prices, also have an impact on the behavior of every economic subject on the market.

Consumption and the behavior of consumers on the tourist market are conditioned by numerous factors, whose interaction has led economic theoreticians to conclude that there exist regular phenomena which create movements of supply and demand.

Some of the examples of developmental aspects of tourism on a global level, are reflected in the overflow of personal and thus also national incomes between countries, but without common export-import licences, treaties or agreements of governments, or any other bilateral cooperation. E.g. if 1000 tourists from Hungary spend in Serbia (each \$1000) one million dollars in total, it means that the sum of personal incomes of 1 million dollars which belong to Hungarian citizens has overflown into Serbia, in Serbia's GNP.

It is especially interesting to mention what Serbia has sold for those one million dollars. It has sold, or exported at home, besides a number of material goods and services, also a number of immaterial values which can neither be packed, standardized, nor in any other way exported, which presents particularities unique to tourism as an economic activity or a model of economic development. 


\section{Literature}

1. Bakić, O., Nikolić, M., Bakić, M. (1999): Osnove turizma sa osnovama ugostiteljstva, Čigoja, Beograd, Republika Srbija.

2. Daković, V. (1992): Antikapital, Naučna knjiga, Beograd, Republika Srbija.

3. Dulčić, A., Petrić L. (2001): Upravljanje razvojem turizma, Mate, Zagreb, Republika Hrvatska.

4. Đuranović, M., Radunović, M. (2011): Analiza efekata turizma na BDP, zaposlenost $i$ platni bilans Crne gore, Podgorica, Centralna banka, Crna Gora.

5. Frolov, D. P. (2011): Teorija kriza posle krize: Tehnologija versus institute, Socijalna Misao, Vol. 24, No. 4, pp. 41-61.

6. Galbraith, J. K. (1987): Economics in Perspective: A Critical History, Houghton Mifflin, Boston, MA.

7. Guzina, S. (2009): Proviđenja Mata Glušca, baška čoeka, Dis Public, Beograd, Republika Srbija.

8. Hunziker, W., Krapf, K. (1942): Grundriss der allgemeinen Fremdenverkehrslehre, Polygraph, Verlag, Zürich, Switzerland.

9. Koncul, N. (2012): Wellness: A new mode of tourism, Ekonomska istraživanja, Vol. 25, No. 2, pp. 503-524.

10. Krippendorf, J. (1986): The new tourist - turning point for leisure and travel, Tourism Management, Vol. 7, No. 2, pp. 131-135.

11. Marx, K., Friedrich, E. (1972): Teorije o višku vrednosti, Deo 2, Prosveta, Beograd, Republika Srbija.

12. Milanović, M. (2007): Osnovi ekonomije, Univerzitet Megatrend, Beograd, Republika Srbija

13. Norsiah, K., Mohd Zaini, A.K. (2012): Tourism and Economics Growth Malaysia: Evidence from Tourist Arrivals from ASEAN-5 Countries, Ekonomska istraživanja, Vol. 25, No. 4, pp. 89-110.

14. Premović, J., Arsić, Lj., Vujović, S. (2012): Globalni strategijsko-razvojni aspekti turizma, VIII Majska konferencija o strategijskom menadžmentu MKCM012, Bor, Republika Srbija, pp. 580-587.

15. Roubini, N., Uzan M. (2006): New International Financial Architecture. Edward Elgar Pub, Northampton, MA.

16. Samuelson, P. (1969): Economics, an Introductory Analysis, McGraw-Hill, New York, NY.

17. Steven, D. L., Stephen, J. D. (2006): Freakonomics: A Rogue Economist Explores the Hidden Side of Everything, Harper Collins Publishers, New York, NY.

18. Stiglitz, J.E. (2014): Inequality, Wealth, and Growth: Why Capitalism is Failing, Lindau, Germany. 
19. Vujović, S., Filipović, S., Marković, S. (2012): Turizam kao podsticajnifaktor ekonomskog razvoja privrede Trebinja, Turistička privreda i povezane teme, Beograd, Republika Srbija, pp. 52-60.

20. Vujović, S., Macura, R., Spajić, J. (2011): Razvojni aspekti turizma (Opština Knić), International scientific meeting: Sustainable agriculture and rural development in terms of the Republic of Serbia strategic goals implementation within Danube region - local communities' development, Banja Vrdnik, Republika Srbija, Vol. 2, pp. 41-46.

21. Vujović, S., Spajić, J., Vukosavljević, D. (2011): Anatomizovanje turističke tražnje u svetlu ekonomskih zakonitosti, fenomena, efekata i paradoksa u potrošnji, Ekonomika poljoprivrede, Vol. 58, No. 4, pp. 563-576.

22. World Tourism Organization (UNWTO). (1998): Tourism Economic Report 1998, Madrid, Spain.

23. World Tourism Organization (UNWTO). (2008): UNWTO Annual Report 2008, Madrid, Spain.

24. World Tourism Organization (UNWTO). (2009): UNWTO Annual Report 2009, Madrid, Spain.

25. World Travel \& Tourism Council (WTTC). (2010): Travel \& Tourism Economic impact 2010, London, UK. 


\title{
UTICAJ TURIZMA NA KRUŽNI TOK EKONOMSKOG PROCESA
}

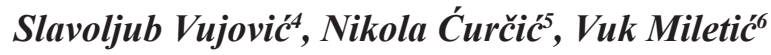

\section{Rezime}

Odnos proizvodnih i potrošnih jedinica, tržišni mehanizmi i ponašanje ekonomskih subjekata na tržištu su aspekti koju omogućavaju spoznaju turizma u ekonomskom procesu.

Dva osnovna faktora turizma "slobodno vreme i slobodan novac" kao cilj stvaralaštva svakog pojedinca, nastojeći da zadovolji potrebe za luksuzom, odmorom, oporavkom i rekreacijom, u direktnoj su vezi sa osnovnim ekonomskim odnosom, odnos između ograničenih dobara $i$ neograničenih potreba. Neuvažavanje principa i zakonitosti socio-ekonomske sfere, od strane dinamike razvoja tehno-ekonomske sfere, sve većih razlika između siromašne većine $i$ bogate manjine, u celom svetu, uzrokuje mnoge ekonomske i društvene probleme. S obzirom na ekonomske probleme na globalnom nivou, dalje pravce razvoja turizma treba tražiti kroz analizu odnosa, ili bolje reći, međuzavisnosti razvoja tehno-ekonomske i socio-ekonomske sfere. U radu se nastoji da se odredi i pojasni značaj turizma kao podsticajnog faktora kružnog toka ekonomskog procesa.

Ključne reči: turizam, ekonomija, razvoj, privreda.

4 Dr Slavoljub Vujović, viši naučni saradnik i profesor strukovnih studija, Beogradska poslovna škola, Visoka škola strukovnih studija, Ulica Kraljice Marije br. 73, 11000 Beograd, Republika Srbija, Telefon: +381 113042 328, E-mail: kelovic1967@yahoo.com

5 MA Nikola V. Ćurčić, student doktorskih studija, Univerzitet Union Nikola Tesla, Fakultet za menadžment, Sremski Karlovci, Srbija, Telefon: +381 6427777 71, E-mail: nikolavcurcic@yahoo.com

6 Mr Vuk Miletić, student doktorskih studija, Univerzitet Privredna akademija, Fakultet za primenjeni menadžment, ekonomiju i finansije, Ulica Nemanjina br. 4, 11000 Beograd, Republika Srbija, Telefon: +381 112643 390, E-mail: vmiletic@gmail.com

EP 2016 (63) 1 (323-337) 